\title{
Isolation and Determination of Protease Enzyme Synthesized by Pseudomonas Sp. from the Gut of Estuarine Fish Etroplus suratensis
}

\author{
Mary Suja $\mathbf{R}^{1 *}$, Arumugam $\mathbf{P}^{2}$, Palavesam $\mathrm{A}^{3}$ and Christudhas Williams $\mathrm{B}^{4}$ \\ ${ }^{1}$ William Research Centre, Nagercoil, India \\ ${ }^{2}$ Departments of Zoology, Bharathiar University, India \\ ${ }^{3}$ Department of Animal Sciences, Manonmaniam Sundaranar University, India \\ ${ }^{4}$ Department of Botany, Scott Christian College, India
}

Submission: June 23, 2017; Published: July 14, 2017

*Corresponding author: Mary Suja R, William Research Centre, Nagercoil, India, Email: rmsuja.83@gmail.com

\begin{abstract}
The protease producing potent microbes isolated from the gut of the estuarine fish Etroplus suratensis collected from the Rajakkamangalam estuary was identified as Pseudomonas sp. The effect of carbon source on protease production inferred that the Pseudomonas sp. prefer maltose for maximizing the protease production $(203.04 \mathrm{U} / \mathrm{ml})$, nitrogen sources prefer casein $(104.77 \mathrm{U} / \mathrm{ml})$, casein enzyme hydrolysate prefer an optimum concentration of $5 \%(191.27 \mathrm{U} / \mathrm{ml})$, metal ion prefer $\mathrm{FeCl} 2(192.75 \mathrm{U} / \mathrm{ml})$, hydrocarbon induced protease production by no nane $(119.40 \mathrm{U} / \mathrm{ml})$, $\mathrm{NaCl}$ on protease production revealed that the Pseudomonas sp. was slightly halophilic required $0.5 \% \mathrm{NaCl}$ for maximizing protease production $(414.70 \mathrm{U} / \mathrm{ml})$, surfactants induced protease production by Triton-X100 had the higher influence on enzyme production $(200.10 \mathrm{U} / \mathrm{ml})$, the optimum $\mathrm{pH} 7.0$ and temperature $40^{\circ} \mathrm{C}$. SDS/PAGE analysis of molecular mass of the partially purified proteolytic enzymes synthesized by the identified proteolysis microbes ranged from 29 to $40 \mathrm{KDa}$.
\end{abstract}

Keywords: Etroplus suratensis; Protease; Rajakkamangalam estuary; Enzymes; Gut

\section{Introduction}

Enzymes are biological catalyst highly specialized with extraordinary catalytic power comprise remarkable specificity. Proteases are the essential constituents of all forms of life on earth including prokaryotes, fungi, plants and animals [1,2]. Increasing demand of protease had lead biotechnologists to explore novel sources of proteases [3]. Microorganisms preferred protease enzymes for fermentation bioprocesses due to their fast growth rate genetically engineered to generate new enzyme with desirable abilities [4,5]. Marine micro-organisms represent one of the potential sources for exploring novel enzymes expected to posse's unique properties due to their unique natural habitat show distinct physiological characteristics, metabolic patterns and nutrient utilization [6]. In general, microbial proteases are extracellular in nature and are directly secreted into the fermentation broth by the producer, thus simplifying downstream processing of the enzyme as compared to proteases obtained from plants and animals $[7,8]$.

The gut plays a crucial role in nutrition, the bacterial attachment to the digestive tract is important in maintaining a stable population with in the gut $[9,10]$. Extracellular protease production in microorganisms is highly influenced by medium component such as carbon and nitrogen ratio, presence of metabolizable sugar such as glucose along with metal ions [11]. Apart from this, the protease production is highly influenced by physical factors such as aeration, inoculum, size, $\mathrm{pH}$, temperature and incubation time [7]. Biological factors such as genetic nature of the organism influence the metabolic or biochemical behaviour of the microbial strain and metabolite production [12]. In commercial practice, the optimization of medium composition with various media components at the end of fermentation is cost-effective metabolite yield [13].

In general, no defined medium has been established for the best production of any metabolite because the genetic diversity present in the microbial sources causes each organisms or strain to possess unique nature for maximum production. Therefore, it is essential to have a detailed investigation on newly isolated microbial strain for production pattern under different environmental conditions in an optimized pattern 
to achieve maximum production [14]. In commercial practice the optimization of medium composition was carried out to maintain a balance between various medium components, thus minimizing the amounts of unutilized components at the end of fermentation. Though the protease productions by bacterial strains were documented well [1-4], the protease productions by fish gut bacterial isolates still stand as lacunae. The main objective of the present work was to investigate the protease production, in the fish gut bacterial isolate.

\section{Materials and Methods}

\section{Sample collection and isolation of gut bacteria}

The pearl spot Etroplus suratensis collected from the Rajakkamangalam estuary (a minor estuary in Southwest coast of India) was transported to the laboratory in a-septic conditions. The gut was dissected out from the animal in a-septic condition, length and weight of the gut was measured. Then the gut was grind well with saline buffer and used as the stock. This stock solution was serially diluted and then spreaded on Zobell marine agar medium plate. The plates were then incubated at 37 oC for 24 to $48 \mathrm{~h}$. The total viable count (TVC) of the colonies was finally noted. The isolated cultures were purified individually by streaking on nutrient agar plates and were sub cultured. Then the bacterial cultures were identified by performing biochemical tests.

\section{Identification of gut bacteria}

The Pesudomonas sp. used for the present study was isolated as a potent proteolytic bacterium from the gut of Etroplus suratensis. About $9 \mathrm{ml}$ distilled water was sterilized. To this $1 \mathrm{ml}$ of stock solution was added and the following dilutions were prepared i.e. 10-1, 10-2, 10-3, 10-4, 10-5 from each dilution $0.1 \mathrm{ml}$ of sample was spread into the petriplates with nutrient agar medium. The plates were incubated at $37^{\circ} \mathrm{C}$ in an inverted position for about $24 \mathrm{hrs}$. After incubation the numbers of colonies formed were counted. In the present study, the colonies recorded 10-4 dilution was alone taken for further enumeration. Consequently, single colony was isolated out and streaked on the already prepared agar slants. Then the agar slants were maintained for further experimental studies.

\section{Mass culture of protease production}

For mass culture, protease producing organism was enriched first using enrichment medium containing beef extract $(0.15 \%)$, peptone $(0.5 \%), \mathrm{NaCl}(0.5 \%)$ and glucose $(0.5 \%)$ at $\mathrm{pH} 7.0$ for $24 \mathrm{hrs}$. Then $5 \mathrm{ml}$ enriched seed culture was inoculated in $250 \mathrm{ml}$ conical flask containing $50 \mathrm{ml}$ basal medium. The composition of basal medium was 3g K2HPO4, 1g Mgso4 7H2O, 3g beef extract, $5 \mathrm{~g}$ peptone and $\mathrm{pH} 7$. The culture was incubated for 72 hour by reciprocal shaking at $30{ }^{\circ} \mathrm{C}$. The cells were then harvested by centrifugation at 10,000 rpm for 15 minutes and the supernatant was used for further assay.

\section{Protease assay}

The assay system consists of the following ingredients: $1.25 \mathrm{ml}$ Trisbuffer (pH 7.2), $0.5 \mathrm{ml}$ of $1 \%$ aqueous casein solution and $0.25 \mathrm{ml}$ culture supernatant. Approximate controls were also made. The mixture was incubated for 30 minutes at $30{ }^{\circ} \mathrm{C}$. Then $3 \mathrm{ml}$ of $5 \%$ TCA was added to this mixture and it forms precipitate was placed at $4{ }^{\circ} \mathrm{C}$ for 10 minutes. Then it was centrifuged at 5000 rpm for 15 minutes. From this $0.5 \mathrm{ml}$ of supernatant was taken, to this $2.5 \mathrm{ml}$ of $0.5 \% \mathrm{Na} 2 \mathrm{Co} 3$ were added and mixed well and incubated for 20 minutes. Then it was added with $0.5 \mathrm{ml}$ of folin phenol reagent and absorbance was taken at $660 \mathrm{~nm}$ using UV-Visible spectrophotometer. The amount of protease produced was found with the help of tyrosine standard graph. Based on the tyrosine released the protease activity was expressed in microgram of tyrosine released by $1 \mathrm{ml}$ of enzyme in 30 minutes at $30^{\circ} \mathrm{C}$ on tyrosine equivalent.

\section{Determination of the molecular mass of partially purified protease enzyme}

The SDS/PAGE in $14 \%$ discontinuous gel was performed using the method of Laemmli. The molecular mass of the partially purified sample was measured by using a series of protein with known molecular weight marker as standard (Obtained from Genei, Bangalore). The molecular mass of the partially purified sample was determined by plotting the values in standard graph with log molecular weight versus mobility. The distance travelled by each protein was measured and mobility was calculated relative to the tracking dye, coomassie brilliant blue.

\section{Results}

\section{Identification of protease positive colony}

Based on the morphological, physiological and biochemical characteristic the protease positive colony was identified as Pseudomonas sp. by following the standard keys of Bergey's Manual of Determinative Bacteriology.

\section{Screening of protease production by Pseudomonas sp.}

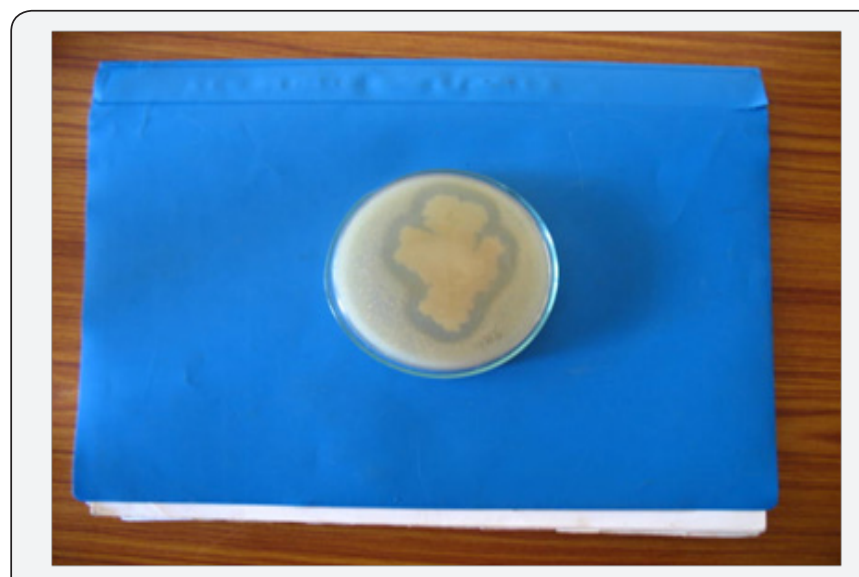

Figure 1: Pseudomonas sp. on skin milk agar plate. 
The isolated bacterial strain was screened for protease producing ability on skin milk agar form a zone due to hydrolysis of case in Figure 1. Hence this strain was identified as a protease producer was used for further studies.

\section{Effect of nitrogen sources on protease production}

The effect of different kinds of nitrogen sources on protease production after 48 hour of incubation period revealed maximum amount of enzyme production in casein $(104.77 \mathrm{U} / \mathrm{ml})$ supplemental medium, followed by fishmeal powder (103.09U/ $\mathrm{ml}$ ) whereas, the minimum amount of protease production was observed in skim milk powder $(36.32 \mathrm{U} / \mathrm{ml})$ supplemented medium.

\section{Effect of carbon sources on protease production}

The effect of carbon sources on protease production after 48 hour of incubation period revealed maximum protease production in maltose $(203.04 \mathrm{U} / \mathrm{ml})$ supplemented medium and minimum protease production in sucrose $(50.60 \mathrm{U} / \mathrm{ml})$ added medium.

\section{Effect of casein enzyme hydrolysate sources on protease production}

The effect of various concentrations of casein enzyme used for protease production after 48 hour of incubation period, showed maximum amount of enzyme production in 5\% casein enzyme added medium (191.27 U/ml).

\section{Effect of hydrocarbons on protease production}

The effect of different kinds of hydrocarbons on protease production after 48 hour of incubation period showed maximum amount of enzyme production recorded in Nonane $(119.40 \mathrm{U} / \mathrm{ml})$ supplemented medium. Dodecane $(119.05 \mathrm{U} / \mathrm{ml})$ was identified as the second best hydrocarbon for the enzyme production. On the other hand minimum amount of protease production was recorded in Hexadecane $(59.00 \mathrm{U} / \mathrm{ml})$ added medium.

\section{Effect of various concentration of sodium chloride on protease production}

The effect of various concentration of $\mathrm{NaCl}$ on protease production after 48 hour of incubation period among the tested concentration showed the maximum amount of enzyme production was observed in $1.5 \% \mathrm{NaCl}(111.91 \mathrm{U} / \mathrm{ml})$ supplemented medium. The lowest amount of enzyme production was recorded in $5.0 \% \mathrm{NaCl}(212.07 \mathrm{U} / \mathrm{ml})$ supplemented medium.

\section{Effect of surfactants on protease production}

The effect of different kinds of surfactants on protease production after 48 hour of incubation period among the tested surfactants showed maximum amount of enzyme production in Triton x $100(200.10 \mathrm{U} / \mathrm{ml})$ added medium. The minimum amount of enzyme production was recorded in control (48.08U/ $\mathrm{ml}$ ) supplemented medium.

\section{Effect of metal ions on protease production}

The effect of metal ions on protease production after 48 hour of incubation period among the tested metal ions, the maximum amount of enzyme production was recorded in Fecl2 (192.75U/ $\mathrm{ml}$ ) added medium. The minimum protease production was recorded in $\mathrm{BaCl} 2(44.72 \mathrm{U} / \mathrm{ml})$ supplemented medium.

\section{Effect of temperature on protease production}

The effect of various temperatures on protease production the maximum protease production was obtained at $40{ }^{\circ} \mathrm{C}$ temperature $(317.69 \mathrm{U} / \mathrm{ml})$ and minimum protease productions at temperature $10 \mathrm{oC}(59.00 \mathrm{U} / \mathrm{ml})$.

\section{Effect of $\mathbf{p H}$ on protease production}

The effect of various $\mathrm{pH}$ on protease production. The maximum protease production was obtained at $\mathrm{pH} 7.0$ (188.97 $\mathrm{U} / \mathrm{ml}$ ) and minimum protease productions at $\mathrm{pH} 10.0$ (34.85U/ $\mathrm{ml})$.

\section{Molecular mass determination}

Molecular mass determination of protease produced by Pseudomonas sp. was estimated based on the Rf value of the markers and the Rf value of the protease as per the SDS-PAGE kit, GENEI, Bangalore. From the results, it was inferred that, in partially purified enzyme preparation a single band was measured about $45 \mathrm{KDa}$ and the crude enzyme contains many bands (Figure 2).

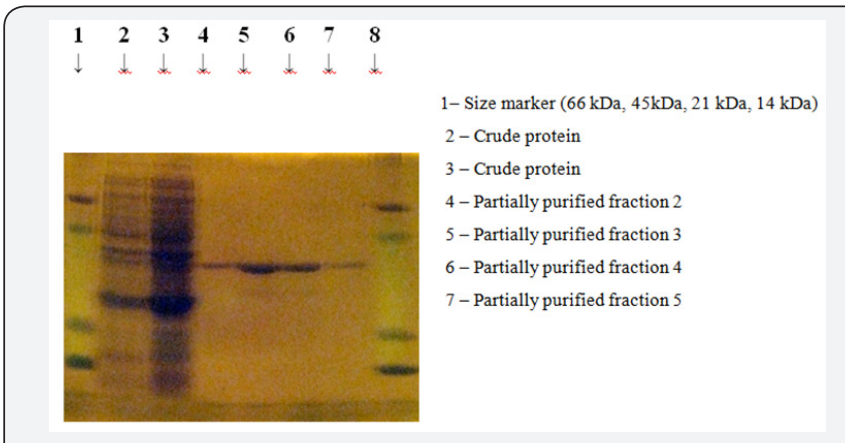

Figure 2: Protein bands obtained by SDS PAGE .

\section{Discussion}

Most marine and estuarine organisms inhabit environment that are relatively rich in bacteria and other microorganisms. The estuarine and seawater may function as a medium for both transport and growth of microorganisms. Thus marine organisms share an ecosystem with microorganisms which in turn responsible for their physiological activities (e.g) digestion or disease. However, the regulations of bacterial population are complex processes, which are not yet fully understood [15]. Among the intestinal gut bacterial enzymes proteases contribute to the development of high added application or products by using the enzyme added digestion proteins which is the major component of the diet. In recent years proteases from the gut of fishes received much attention [16]. But very scare information 
available in the area of their gut bacterial enzymes and its role in the intestine. Another important aspect to be studied is the role of intestinal microflora in nutrition due to the release of extracellular enzymes such as proteinases participating in the hydrolysis of complex biopolymers which is present in the feed. Considering the important point noted above the present study was also designed to evaluate the protease \& cellulose producing ability of Bacillus sp. isolated from the gut of estuarine fish Etroplus suratensis [17].

The cost of microbial proteases or any enzymes is largely determined by the yield which is related to the amount of enzyme produced in downstream processing and post harvest stability. Among the various factors influencing the protease production, the nutrient sources such as carbon and nitrogen sources have thoughtful effect on the production of microbial protease. Each microorganisms used in bioprocess have its own physiological factors and nutritional factors. So it is important to supply the suitable nutrient sources for getting maximum yield. Considering this the effect of various nitrogen sources on protease production was tested. The result showed that casein enzyme hydrolysate $(104.77 \mathrm{U} / \mathrm{ml})$ and fish meal gave their maximum influence on protease production $(103.09 \mathrm{U} / \mathrm{ml})$ respectively. Here an inorganic nitrogen source showed little effect on the protease production. This is because organic nitrogen sources such as casein enzyme hydrolysate and fish meal not only serve as nitrogen sources but also they have high energy sources such as carbohydrates, free amino acids. It was proved by the previous studies, where the production by the haloalkalophilic Bacillus clausii was higher when the medium supplies with casein. The results of this present study on the case in improved protease production also supports the previous studies on casein aided higher protease production by Virgibacillus panthothenticus [18].

Carbon source is a primary energy source, which have important role in the improvement of bioprocessing of biochemical by supplying the suitable carbon sources, we can achieve better yield. The experiment on the effect of various carbon sources on protease production showed that maltose and lactose gave higher production than other supplied carbon sources. There are several reports showing that different carbon sources have different influence on enzyme production by different bacteria and fungi. But in this particular strain, maltose gave its maximum influence on protease production. In relation to this present study, some bacteria such as Bacillus sp. and Bacillus clausii reported that the production by these bacteria were high in maltose supplied medium. Also this study supports the positive effect of maltose on protease production by Aspergillus tamari, Bacillus alkalophiles and Arthrobacter ramosus [19].

Organic solvent tolerant enzymes have comes into focus for past few years due to its versatile use in industrial level. In the present study the effect of various organic solvents on the protease production revealed that the bacteria utilize all the supplied organic solvents and produced solvent stable protease over the control. Among the supplied organic solvents and produced solvent stable protease over the control. The protease production was remarkably high in the medium chain hydrocarbon-Nonane supplied medium $(119.40 \mathrm{U} / \mathrm{ml})$. This study showed that the experimental bacterium has the tendency to break the solvents and utilize as a nutrient source for protease production, using this ability, this bacterium can be used in the organic synthesis reactions. There are some organic solvent tolerant proteases producing microorganisms also reported in previous studies. The present study finds supports with the organic solvent tolerant protease production by halophilic archaean, Natrialba magadii and Bacillus pumalis [20].

Sodium chloride is an important physico-chemical factor for any marine and estuarine animal to maintain the osmoregulation for successive growth and fermentative production. Considering the importance of sodium chloride, the present study was conducted and the results showed that this bacterium can use the salt range between $0.5-5.5 \%$ for maximizing the protease production and it was remarkably high in $0.5 \%$ sodium chloride $(414.70 \mathrm{U} / \mathrm{ml})$ supplied medium. At high concentration, the protease production decreased due to osmoregulation problems. These results showed that the candidate bacterium is moderately halophilic because it is an estuarine isolate [21]. The protease production by marine bacterium Roseobacter Sp. absolutely requires $1.0 \% \mathrm{NaCl}$ Similar results are also reported in Pseudomonas sp. and Salini vibrio sp. [22].

Surfactants are one of the chemical or nutritional factors which were identified to improve fermentation process. The present study on the effect of various surface active agents on the fermentative production of protease revealed that Triton $\mathrm{X} 100$ was found to increase the protease production over the control. Among all other surfactants and detergent tested the bacteria yield $70-90 \%$ of protease produced over the control. The results from the study proved that this protease can be applied in detergent industry. Concurrent to this present study, some other bacteria are previously reported to produce improved protease by addition of surfactants reported that the protease from Bacillus clausii and Bacillus sp. retain their activity with different surfactants such as Triton X 100, Tween 20 and SDS. The present study also supports the positive influence of Triton X 100 on protease activity by Bacillus sp. [23].

Metal ions and trace elements are often required by bacterium for its growth and physiological activities. Especially enzyme bio processing is very important because some enzymes like protease require specific metal ions for its structural and functional stability. The present study on the effect of metal ions and trace elements on protease production revealed that the calcium, mercury, ammonium ions had profound effect on the protease production. Hence all these metal ions were found to be a activator for protease. This same phenomenon was reported in 
some bacteria and fungi in previous study reported that protease from Aspergillus sp. showed maximum activity with metal ions such as $\mathrm{ca}^{2+}, \mathrm{mg}^{2+}$ and inhibited by EDTA [24].

$\mathrm{pH}$ in the fermentation media is a main factor deciding the effective fermentation process. $\mathrm{pH}$ of the medium is not a stable one and the results on the effect of initial $\mathrm{pH}$ of fermentation media on protease production revealed that this bacterium produces protease at wide range of $\mathrm{pH}$ from 3-10 and it was high in $\mathrm{pH}$ 6. The results showed that this protease active over wide range of $\mathrm{pH}$ from 3-6 and with minimum activity in each $\mathrm{pH}$. Consistence with the present study reported neutral protease production by Aspergillus sp. This study also supports the protease production of Halogeometricum sp. [25].

Like $\mathrm{pH}$, temperature is also a critical physical factor in fermentation. The effect of various incubation, temperature on protease production resulted that $50{ }^{\circ} \mathrm{C}$ was found to be a suitable temperature range for this bacterium. The fact is above the temperature of $50{ }^{\circ} \mathrm{C}$, the physiological activities of the bacterium may be accelerated. This was supported by the maximum activity shown by Virgibacillus panthothenticus at the temperature range between $30-50{ }^{\circ} \mathrm{C}$. This also supports the previous studies on the higher protease production by Aspergillus oryzae (U1521) at $45^{\circ} \mathrm{C}$ [26].

\section{Conclusion}

From the present study, it is evidenced that Pseudomonas sp. isolated from the gut of E. suratensis is a potent species that can be used for the industrial large scale production of protease in the optimized environmental nutritional conditions.

\section{References}

1. Sreeja SJ, Malar JPW, Joseph SFR, Tiburcius S, Immanuel G, et al. (2013) Optimization of cellulase production by Bacillus altitudinis APS MSU and Bacillus licheniformis APS2 MSU, gut isolates of fish Etroplus suratensis. Int J Advanc Res Technol 2(4): 123-132.

2. Banerjee CW, Sani RK, Azmi W, Soni R (1999) Thermostable alkaline protease from Bacillus brevis and its characterization as a laundry detergents additive. Process Biochem 35: 213-219.

3. Joo HS, Chang CS (2005) Production of protease from a new alkalophilic Bacillus sp. I-312 grown on soybean meal: optimization and some properties. Process Biochem 40(3-4): 1263-12701.

4. Ann Suji H, Palavesam TA, Immanuel G, Raj S (2014) Production of different enzymes by gut microflora, IJSN 5(1): 28-32.

5. North MJ (1982) Comparative biochemistry of the proteinases of eukaryotic micro-organisms. Microbiol rev 46(3): 308-340.

6. Jackson EN, Young L (2001) Ecology and Industrial Microbiology, learning and earning from diversity. Current Opin Microbiol 4: 281285

7. Suppiah S, Sendeshkannan K, Prabakaran P, Rajkumar G, Yasothkumar $N$ (2012) Purification and characterization of alkaline protease from Lysini Bacillus fusiformis. J Biochem Technol 4(1): 561-564.

8. Kumar CG, Takagi H (1999) Microbial alkaline proteases from bioindustrial viewpoint. Biotechnol Advanc 17(7): 561-594.

9. Conway P, Malk L, Mitchell R, Kjelleerg S (1986) Starvation of the marine flounder, squid and laboratory mice and its effect on the intestine microflora. FEMS micr Ecol 38(1986): 187-195.

10. Balaji N, Rajasekaran KM, Kanipandian N, Vignesh V, Thirumurugan R (2012) Isolation and screening of proteolytic bacteria from freshwater Fish Cyprinus carpio. Int Mult Res J 2(6): 56-59.

11. Gupta R, Beg T, Lorenz P (2002) Bacterial alkaline proteases molecular approaches and industrial applications. Appl Microbiol Biotechnol 59(1): 15-22.

12. Varela H, Ferrari MD, Belobradjic L, Weyraueh R, Loperena ML (1996) Effect of medium composition on the production of a new Bacillus isolate of protease with promising unharing activity. World J Microbiol Biotechnol 12(6): 643-645.

13. Hameed A, Keshavarz T, Evans CS (1999) Effect of dissolved oxygen and $\mathrm{pH}$ on the production of extracellular proteases from a new isolate of Bacillus subtilis K2. For use in leather processing. J Chem Technol Biotechnol 74: 5-8.

14. Prakasham RS, Suba Rao CH, Sarma PN (2006) Green gram husk and inexpensive substrate for alkaline protease production by Bacillus sp in solid state fermentation. Bioresour Technol 97(13): 1449-1454.

15. Elliah P, Adinarayana K, Pardhasaradhi SV, Srinivasulu B (2002) Isolation of alkaline protease producing bacteria from Visakhapatanam soil. Ind J Microbiol 42: 173-175.

16. Hansen GH, Olfsen JA (1999) Bacterial interactions in early life stages of marine cold water. Microb Ecol 38(1): 1-26.

17. Chu WH (2007) Optimization of extracellular alkaline protease production from species of Bacillus. J Ind Microbiol Biotechnol 34(3): 241-245.

18. Ganesh Kumar C, Han-Seung, Jo Yoon- Mu Koo, Seung R, Paik, et al. (2003) Thermostable alkaline protease from a novel marine haloalkalophilic Bacillus clausii isolates. World J Microbiol Biotechnol 20(4): 351-357.

19. Kanekar PP, Nilegaonkar S, Sarnaik SS, Kelkar AS (2002) Optimization of protease activity on alkalophilic bacteria, isolated from an alkaline lake in India. Bioresour Technol 85(1): 87-93.

20. Abdul Rahman RNZR, Mohamed S, Salleh AB, Basri M (2007) A new organic solvent tolerant protease from Bacillus pumitus 115b. J Ind Microbiol Biotechnol 34: 509-517.

21. Priya SS, Krishnaveni J, Selvin J, Gandhimathi R, Kumar MA, et al. (2008) Optimization of extracellular thermotolerant alkaline protease produced by marine Roseobacter sp. (MMD040). Bioprocess Biosyst Eng 31(5): 427-433.

22. Amoozegar MA, Fatemi AZ, Karbalaei-Heidari HR, Razavi MR (2006) Production of extracellular alkaline metalloprotease from newly isolated, moderately Halophilic Salini vibro strain. Microbiol Res 162(4): 369-377.

23. Joo HS, Kumar GC, Park CG, Paik SR, Chang CS (2003) Oxidant and SDS- stable alkaline protease from Bacillus clausii I-52: production and some properties. J Appl Microbiol 95(2): 267-272.

24. Sumantha A, Sandhya C, Szakacs G, Soccol CR, Pandey A (2005) Production and Partial purification of a Neutral Metalloprotease by Fungal Mixed substrate Fermentation. Food Technol Biotechnol 43(4): 313-319.

25. Vidyasagar M, Prakash SB, Sreeramulu (2006) Optimization of culture conditions for the production of haloalkalophilic thermostable protease from an extremely halophilic archeon Halogeotricum Sp. Tss 101. Lett Appl Microbiol 43: 385-391.

26. Samarntarn W, Cheevadhanarak S, Tanticharoen M (1999) Production of alkaline protease by a genetically engineered Aspergillus oryzae U, 521. J Gen Appl Microbiol 45: 99 -103. 
This work is licensed under Creative Commons Attribution 4.0 Licens DOI: 10.19080/JOJMS.2017.02.555586
Your next submission with Juniper Publishers will reach you the below assets

- Quality Editorial service

- Swift Peer Review

- Reprints availability

- E-prints Service

- Manuscript Podcast for convenient understanding

- Global attainment for your research

- Manuscript accessibility in different formats

( Pdf, E-pub, Full Text, Audio)

- Unceasing customer service

Track the below URL for one-step submission https://juniperpublishers.com/online-submission.php 